\title{
Synaptic Mechanisms of Temporal Diversity in the Lateral Geniculate Nucleus of the Thalamus
}

\author{
Leif E. Vigeland, Diego Contreras, and Larry A. Palmer \\ Department of Neuroscience, University of Pennsylvania Perelman School of Medicine, Philadelphia, Pennsylvania 19104
}

The lateral geniculate nucleus (LGN) contains a unique and numerous class of cells called lagged cells, which introduce a time delay into the neural signal provided to cortex. Previous studies have shown that this delay is dependent on $\mathrm{GABA}_{\mathrm{A}}$ receptors within the LGN. Furthermore, lagged cells have distinct integrative properties with a slower rising, more sustained, and overall lower firing rates than nonlagged cells. We have recorded intracellularly from lagged cells in the cat LGN and found a unique property of their retinal inputs that underlies both their temporal and integrative visual response properties. Lagged cell EPSPs, which often derive from a single retinal input, have smaller amplitudes, repolarize more quickly, and are followed by a $\mathrm{Cl}^{-}$-dependent hyperpolarization compared with nonlagged cells. The $\mathrm{Cl}^{-}$-dependent hyperpolarization sums early in the visual response generating a powerful synaptic inhibition that coincides with the peak frequency of retinal input and delays the spike response in lagged cells. The hyperpolarization subsides rapidly over $\sim 20-40 \mathrm{~ms}$ allowing for slow summation of the retinal input leading to the visual spike response. Given the tight association of single retinal EPSPs and the following inhibition, we propose that both functional properties result from the triadic circuitry prevalent in the LGN and particularly prominent in lagged X-cells. Thus, our results show for the first time a dynamic interaction of retinal excitation and fast feedforward inhibition that determines the integrative properties and the delay in firing of lagged cells.

\section{Introduction}

Intrinsic cellular properties and circuitry within the lateral geniculate nucleus (LGN) modify the neural representation of the visual scene provided by retinal ganglion cells (RGC). In addition to spatial processing, notably stronger surround suppression (Hubel and Wiesel, 1961), the LGN alters the representation in the time domain (Mastronarde, 1987a; Humphrey and Weller, 1988a; Wolfe and Palmer, 1998). In particular, Mastronarde (1987a) identified a class of LGN relay cells whose responses are delayed in time. These lagged $\left(X_{L}\right)$ cells and their nonlagged $\left(X_{N}\right)$ counterparts receive excitatory drive from a homogeneous population of RGCs but, whereas nonlagged cells follow the discharge pattern of the RGC input, excitation in lagged cells is delayed by a leading suppression. In lagged X-cells, this leading suppression coincides with the peak discharge rate of the RGC input. Both the delayed excitation and the leading suppression are abolished by pharmacological blockade of $\mathrm{GABA}_{\mathrm{A}}$ receptors (Heggelund and Hartveit, 1990). $\mathrm{X}_{\mathrm{L}}$ cells are abundant in the LGN accounting for up to $40 \%$ of the relay X-cell population (Mastronarde, 1987a) and provide a delayed signal to cortex that is thought to contribute significantly to the emergence of

\footnotetext{
Received Aug. 23, 2012; revised Nov. 5, 2012; accepted Nov. 23, 2012.

Author contributions: L.E.V., D.C., and L.A.P. designed research; L.E.V., D.C., and L.A.P. performed research; L.E.V. and L.A.P. analyzed data; L.E.V., D.C., and L.A.P. wrote the paper.

This work is funded by the National Eye Institute (NEI) Grant R01EY020765 and NEI Vision Training Grant T32EY007035. We would like to acknowledge Herminio Guajardo for experimental help and Ben Halterman and members of the Contreras lab for their helpful discussion of this work.

Correspondence should be addressed to Diego Contreras, Department of Neuroscience, University of Pennsylvania Perelman School of Medicine, 215 Stemmler Hall, Philadelphia, PA 19106-6074. E-mail: diegoc@mail.med.upenn.edu.

DOI:10.1523/JNEUROSCI.4046-12.2013

Copyright (C) 2013 the authors $\quad 0270-6474 / 13 / 331887-10 \$ 15.00 / 0$
}

direction-selective cells in layer 4 (Adelson and Bergen, 1985; Saul and Humphrey, 1990).

The rapid onset of the $\mathrm{GABA}_{\mathrm{A}}$-mediated leading suppression suggests involvement of local thalamic interneurons. Early electron microscopic studies of thalamic relay nuclei including the LGN identified a unique synaptic architecture where the principle afferents make excitatory contacts onto dendrites of relay neurons and also dendritic processes of local inhibitory neurons (Famiglietti and Peters, 1972; Hamos et al., 1985). The latter in turn make inhibitory contacts on the same relay cell dendrites receiving the direct afferent excitation. These triadic synapses are formed on grape-like appendages of the relay cell dendrite and the entire structure is enclosed within a glial sheath. In the LGN, Humphrey and Weller (1988a) found these grape-like appendages to be present at many branch points within the dendritic trees of all $\mathrm{X}_{\mathrm{L}}$ cells but relatively few $\mathrm{X}_{\mathrm{N}}$ cells. This circuitry predicts a feedforward inhibition tightly locked $(\sim 1 \mathrm{~ms})$ to optic tract single inputs, which has been identified in 34\% of mouse LGN neurons in vitro and shown to control spike number and increase spike precision (Blitz and Regehr, 2005).

Here, using intracellular recording in vivo, we report on the synaptic events underlying the initial spike suppression and leading inhibition in the responses of $\mathrm{X}_{\mathrm{L}}$ cells to a same-sign contrast stimulus (bright spot for an on-center cell) limited to the receptive field (RF) center. We show for the first time that the retinal EPSPs in $\mathrm{X}_{\mathrm{N}}$ cells have larger amplitudes and consist of a single excitatory event but that those in $\mathrm{X}_{\mathrm{L}}$ cells have smaller amplitudes and consist of an EPSP-IPSP complex. These unique synaptic events can account for the delayed spike responses to visual stimuli and give further support to the hypothesis that the distinct responses of lagged and nonlagged $\mathrm{X}$-cells follow from their ret- 
inal patterns of synaptic input: direct dendritic excitation in $\mathrm{X}_{\mathrm{N}}$ cells and triadic excitation-inhibition in $\mathrm{X}_{\mathrm{L}}$ cells.

\section{Materials and Methods}

Surgical procedures. Experiments were conducted in accordance with the ethical guidelines of the National Institutes of Health and with the approval of the Institutional Animal Care and Use Committee of the University of Pennsylvania. Adult male cats $(2.5-3.5 \mathrm{~kg})$ were anesthetized with an intraperitoneal injection of Nembutal $(25 \mathrm{mg} / \mathrm{kg})$ followed by supplemental isoflurane $\left(2-4 \%\right.$ in $70 \% \mathrm{~N}_{2} \mathrm{O}$ and $\left.30 \% \mathrm{O}_{2}\right)$. The animal was paralyzed with gallamine triethiodide (Flaxedil) and artificially ventilated (end tidal $\mathrm{CO}_{2}$ held at $3.8-4.0 \%$ ). Anesthesia was maintained by continuous infusion of Nembutal (3-10 mg/kg-h) throughout the experiment (12-16 h). Heart rate, blood pressure, and electroencephalogram were continuously monitored. Rectal temperature was maintained at $37-38^{\circ} \mathrm{C}$.

A craniotomy and durotomy were made at Horsley-Clarke coordinates A6 and L9 and a warm solution of agar (3.5\%) was injected between the dura and the brain. The stability of the recordings was further improved by a bilateral pneumothorax, drainage of the cisterna magna, and hip suspension. Intracellular recordings from laminae A and A1 of the LGN were made with glass pipettes (40-80 M 2 ) filled with $3 \mathrm{M}$ potassium acetate (except as noted in the text). In some experiments, a bipolar stimulating electrode was placed straddling the optic chiasm.

Visual stimulation. The corneas were protected with neutral contact lenses after dilating the pupil with $1 \%$ atropine and retraction of the nictitating membrane with $1 \%$ phenylephrine $\mathrm{HCl}$ (Neo-Synephrine). Spectacle lenses were chosen by the tapetal reflection technique (Fernald and Chase, 1971) to optimize the focus of stimuli on the retina. The position of the monitor was adjusted so as to center the area centralis on the screen.

Stimuli were generated by writing to the framestore portion of a Cambridge Research Systems visual stimulus generation card mounted in a conventional PC and presented on an Image Systems model M09LV monochrome monitor operating at $125 \mathrm{frames} / \mathrm{s}$, a spatial resolution of $1024 \times 786$ and mean luminance of $47 \mathrm{~cd} / \mathrm{m}^{2}$. The screen subtends 36 by $27^{\circ}$ (28.7 pixels per degree), and lookup tables were linearized for a contrast range of $\pm 100 \%$. Custom software allowed for interleaving of visual stimulus protocols with injection of currents through the recording electrode and on-line display of acquired signals. Computer-assisted hand-plotting routines were used with every cell to provide initial estimates of critical parameters, especially the location and size of a region of interest spanning the RF in space. All final analysis was performed offline in MATLAB from records stored on a Nicolet Vision (LDS), which included $V_{\mathrm{m}}$, injected current, and stimulus marks, all sampled at $10 \mathrm{kHz}$ and 16 bits.

RF structure was estimated by forward averaging of $V_{\mathrm{m}}$ and spikes with several thousand frames of precomputed lowpass filtered white noise. Spikes were removed from the $V_{\mathrm{m}}$ numerically before averaging. The noise was $16 \times 16$ in space, covering $2 \times 2^{\circ}$ to $5 \times 5^{\circ}$, and frame duration was $16 \mathrm{~ms}$. The resulting estimate of the $3 \mathrm{D}$ spatiotemporal weighting function was displayed as the average bright correlation minus the average dark in steps of $10 \mathrm{~ms}$ out to $320 \mathrm{~ms}$. The main purpose of this measurement was to precisely center other stimuli on the RF and to rigorously choose stimuli that were limited to either the center or the surround. In addition, we often obtained area summation curves with flashed rings or disks to further assure that stimuli were appropriately sized.

Cell classification. Cells were classified as X or Y based on several tests including RF size and their responses to counterphased sinusoidal gratings. Only X-cells are reported here since no clear lagged Y-cells were observed. Cells were classified as on-center if dark stimuli in the center suppressed spike output and bright in the center elevated spike output for a prolonged period. Off-center cells were defined reciprocally.

Two-thirds $(66 \%)$ of our population of X-cells were classified as single-input cells (Mastronarde, 1987b), meaning that they received a single excitatory input from the retina. This was established based on the unitary nature of the EPSP amplitudes observed during spontaneous activity and the fact that these EPSPs exhibited reasonable refractory periods $(>1.8 \mathrm{~ms})$ as seen in interspike interval histograms. EPSPs were detected as threshold crossings of the first derivative of the $V_{\mathrm{m}}$ and were also checked by eye, especially during presentation of optimal visual stimuli where firing rates are high, and depression of the EPSP amplitude was significant.

Conductance and reversal potential estimations. The membrane conductance and reversal potential at each point during a synaptic response was calculated as in Higley and Contreras (2003). Synaptic responses were elicited by flashed stimuli at multiple $V_{\mathrm{m}}$ levels by varying the amount and sign of injected current. The total conductance was taken as the inverse slope of the resulting $V$--I relationship $\left(G_{\text {tot }}\right)$. Subtracting $G_{\text {tot }}$ calculated during a preceding $50 \mathrm{~ms}$ baseline period (resting conductance) from the $G_{\text {tot }}$ calculated during the synaptic response to a visual stimulus gives a measure of the total evoked synaptic conductance, $G_{\text {syn }}$. To calculate $E_{\text {rev }}$, we fit a linear function to a plot of delta $V_{\mathrm{m}}$, calculated as the difference between the $V_{\mathrm{m}}$ during the synaptic response and the resting $V_{\mathrm{m}}$, versus resting $V_{\mathrm{m}}$. The $E_{\text {rev }}$ of the synaptic response equals the $x$-intercept of this curve.

Statistical analysis. Population data are reported as mean \pm SD. Significance was calculated using two-tailed unpaired t tests.

\section{Results}

\section{Database and cell identification}

We obtained intracellular recordings from 89 neurons from the dorsal laminae of the LGN of barbiturate anesthetized cats. Fiftyfive cells were included in the database and had a stable membrane potential $\left(V_{\mathrm{m}}\right)$ more negative than $-60 \mathrm{mV}(-65 \pm 7 \mathrm{mV})$ and input resistance $>15 \mathrm{M} \Omega$. All recorded cells showed the electrophysiological characteristics of thalamic relay cells, notably, a rebound spike-burst riding on a low-threshold spike (Jahnsen and Llinás, 1984) at the offset of hyperpolarizing current pulses from resting $V_{\mathrm{m}}$. We classified our cells as X-cells $(n=27)$ or Y-cells $(n=$ 21 ) according to established criteria (Enroth-Cugell and Robson, 1966; Hoffmann et al., 1972). In addition, seven LGN cells remained unclassified. From the X-cell population, 11 neurons were classified as lagged cells $\left(\mathrm{X}_{\mathrm{L}}\right)$ and the remainder $(n=16)$ were nonlagged cells $\left(X_{N}\right)$ (Mastronarde, 1987a). There were no lagged cells among our Y-cell population.

\section{Lagged cell classification}

We distinguished $\mathrm{X}_{\mathrm{L}}$ from $\mathrm{X}_{\mathrm{N}}$ cells by their distinct responses to a same-sign contrast stimulus limited to their RF center (defined by forward correlation of $V_{\mathrm{m}}$ with spatiotemporal white noise; Wolfe and Palmer, 1998; Niell and Stryker, 2008). Figure 1 compares the spiking and synaptic behaviors of four $\mathrm{X}_{\mathrm{L}}$ (Fig. 1A) and four $\mathrm{X}_{\mathrm{N}}$ (Fig. $1 B$ ) cells in response to a same-sign contrast spot. We recorded synaptic responses while injecting depolarizing and hyperpolarizing current pulses and the analysis of voltage versus injected current will be presented below. In these eight example cells, peristimulus time histogram (PSTH) and spike rasters were plotted from depolarized current levels to emphasize the differences in response properties. All $\mathrm{X}_{\mathrm{N}}$ cells demonstrated an early increase in firing rate whereas $X_{L}$ cells demonstrated an initial suppression of firing with respect to baseline, which was followed by a delayed increase in firing rate. Furthermore, $X_{L}$ cells showed characteristically lower and more sustained firing rates than $X_{N}$ cells. Underlying the spike output of the $\mathrm{X}_{\mathrm{N}}$ cells, the stimulus locked average $V_{\mathrm{m}}$ showed an early depolarization followed by a small repolarization that paralleled the accommodation in firing rate (Fig. $1 B, V_{\mathrm{m}}$, dashed lines represent approximate onset of synaptic response). When measured with depolarizing current, the $\mathrm{X}_{\mathrm{L}}$ cells showed a leading hyperpolarization underlying the cessation of firing, which slowly gave way to a modest depolarization leading to an increase in firing rate (Fig. $1 A, V_{\mathrm{m}}$ ). Thus, the underlying $V_{\mathrm{m}}$ responses explain the spiking behavior of the 

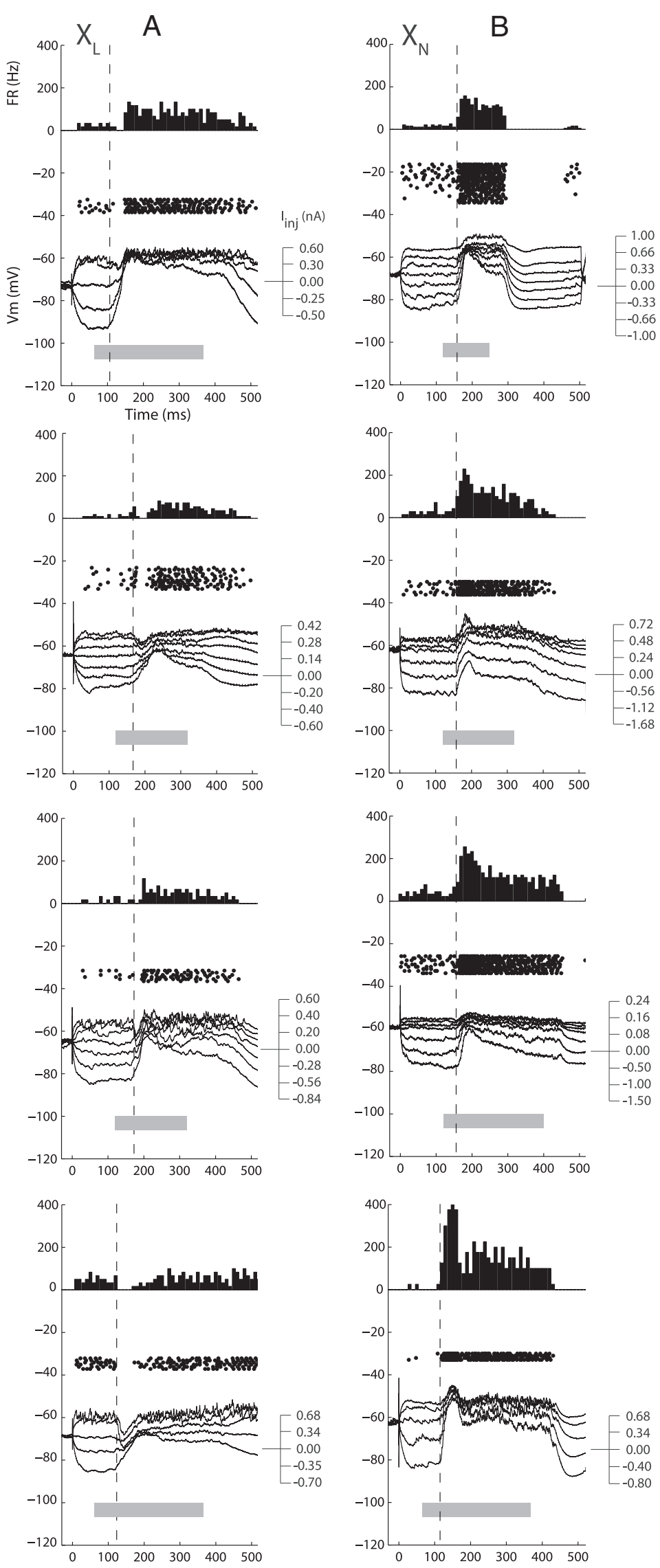

Figure 1. Examples of responses to same-sign contrast stimuli in $X_{L}$ and $X_{N}$ cells. In all cells, a stimulus of same-sign contrast was presented in the $\mathrm{RF}$ center at the time indicated by the gray rectangle shown below $V_{\mathrm{m}}$ traces. Averaged synaptic responses to two cell classes, $\mathrm{X}_{\mathrm{L}}$ cells show an early inhibition followed by a slower rising, more sustained and smaller amplitude depolarization, while $\mathrm{X}_{\mathrm{N}}$ cells show a nondelayed, faster rising and larger depolarization with various degrees of accommodation. We classified all cells that responded to a same-sign contrast stimulus with an initial inhibition, followed by depolarization and an increase in firing rate as $\mathrm{X}_{\mathrm{L}}$ cells.

As opposed to the distinct responses to same-sign contrast stimuli described above, the responses to opposite-sign contrast stimuli were similar in $\mathrm{X}_{\mathrm{L}}$ and $\mathrm{X}_{\mathrm{N}}$ cells. Figure 2 shows the response of an $X_{L}$ and an $\mathrm{X}_{\mathrm{N}}$ cell to a flashed spot in the RF center of same-sign ( $A, B$, top) and opposite-sign ( $A, B$, bottom) contrasts. As in the examples in Figure 1, visual stimuli were presented during depolarizing or hyperpolarizing current injection to reveal the nature of the synaptic response, i.e., synaptic inhibition is increased in amplitude by depolarization and reversed or reduced in amplitude by hyperpolarization. Both the $\mathrm{X}_{\mathrm{N}}$ and $\mathrm{X}_{\mathrm{L}}$ cells were on-center cells and showed characteristic $V_{\mathrm{m}}$ and spike responses to a bright contrast stimulus as described above. To illustrate the delaying effect of the early inhibition in the $\mathrm{X}_{\mathrm{L}}$ cell, we chose two example cells with a similar latency to the onset of the synaptic response (vertical dashed line, latency of $\mathrm{X}_{\mathrm{N}}=36 \mathrm{~ms}, \mathrm{X}_{\mathrm{L}}=39 \mathrm{~ms}$, measured from the most hyperpolarized $V_{\mathrm{m}}$ ). While the spike output of the $\mathrm{X}_{\mathrm{N}}$ cell started with the same latency as the synaptic response, the $\mathrm{X}_{\mathrm{L}}$ cell spike output was delayed by $20 \mathrm{~ms}$ with respect to the onset of the synaptic response. This comparison shows unequivocally that for two LGN neurons receiving retinal input with the same latency, the $\mathrm{X}_{\mathrm{L}}$ cell produces a delayed output. This delay, shown for the first time here to be caused by an actual IPSP, is of similar duration as that reported by Mastronarde (1987b) using dual simultaneous extracellular recordings between RGCs and LGN $\mathrm{X}_{\mathrm{L}}$ cells. In contrast, in response to a dark center stimulus, the spontaneous firing rate (evoked by depolarizing current) was completely suppressed in both cells 30-40 ms after stimulus onset and for the whole duration of the

$\leftarrow$

multiple spot presentations are shown while depolarizing or hyperpolarizing the cell with multiple levels of current injection $\left[I_{\text {inj }}(n A)\right]$. PSTHs (FR, firing rate) and spike rasters are taken from depolarized current levels. $\boldsymbol{A}, X_{L}$ cells show an initial hyperpolarization and suppression of firing followed by depolarization and an increase in firing rate. $\boldsymbol{B}, X_{N}$ cells show initial depolarization along with an increase in firing rate. 
stimulus (Fig. 2A, $B$, bottom). Thus, the opposite-sign contrast stimulus suppressed firing in all $\mathrm{X}_{\mathrm{L}}$ cells, while the same-sign contrast evoked an initial suppression followed by an increase in firing rate.

$\mathrm{X}_{\mathrm{L}}$ cells are defined in extracellular recordings by the delay between stimulus onset and the visually driven increase in firing rate (Mastronarde, 1987a; Humphrey and Weller, 1988a; Saul, 2008). We quantified this delay in our intracellular recordings by measuring the latency to the halfmaximal firing rate (measured from the PSTH generated from resting and depolarized current levels for $\mathrm{X}_{\mathrm{L}}$ and $\mathrm{X}_{\mathrm{N}}$ cells; Fig. $3 A, B$ ) in response to a spot of samesign contrast limited to the RF center. The distribution of half-rise latencies (Fig. 3C) showed a small overlap but all $\mathrm{X}_{\mathrm{N}}$ cell halfrise times were shorter than $70 \mathrm{~ms}$ (56 \pm $13 \mathrm{~ms}, n=16$ ) while all but one $\mathrm{X}_{\mathrm{L}}$ cell half-rise times were equal to or $>70 \mathrm{~ms}$ (96 $\pm 34 \mathrm{~ms}, n=11$; Fig. 3B). To further separate our populations, we looked to incorporate a measurement of the retinal inputs since a delay in LGN firing could be due to a delay in its retinal input.

We measured the latency of the retinal input for each cell as the time when the stimulus-locked average $V_{\mathrm{m}}$ deviates $2 \mathrm{SD}$ above the baseline noise (Fig. $3 A, B$, bottom, $V_{\mathrm{m}}$ ). This measurement was made while injecting hyperpolarizing current so that all synaptic responses were depolarizing. This time point represents the abrupt onset of the barrage of visually driven EPSPs of retinal origin (rEPSPs; Fig. $3 A, B$, bottom, Single Trials). Surpris-

ingly, the latency of retinal input showed a large variability among neurons, spanning 30-70 ms after the onset of the visual stimulus (Fig. 3D, rEPSP Onset Time), a larger range than previously observed (Mastronarde, 1987a; Jin et al., 2011). The distribution of retinal input latencies among $X_{L}$ and $X_{N}$ cells was in part responsible for the overlap seen in our spike output latency distribution (Fig. 3C). When the PSTH half-rise times are plotted against retinal input latency (Fig. $3 D$, left), all $\mathrm{X}_{\mathrm{L}}$ cells (gray dots) had longer delays than $\mathrm{X}_{\mathrm{N}}$ cells (black dots) for each given retinal input latency. This can be seen more clearly by subtracting the retinal input latency from the half-rise time for each cell (Fig. 3D, right). In the subtraction plot it is clear that spike output of $X_{L}$ cells is effectively delayed ( $>20 \mathrm{~ms}$ ) from their retinal input in comparison with $\mathrm{X}_{\mathrm{N}}$ cells $(<20 \mathrm{~ms})$. Therefore, and as already clearly illustrated by the example in Figure 2, the leading inhibition of the visual response in $\mathrm{X}_{\mathrm{L}}$ cells serves to further delay the spiking response.

\section{Synaptic substrates of the leading inhibition in lagged cells}

To characterize the postsynaptic mechanisms underlying their visual responses, we recorded from $\mathrm{X}_{\mathrm{L}}$ and $\mathrm{X}_{\mathrm{N}}$ cells while injecting depolarizing and hyperpolarizing current pulses in combination with the presentation of visual stimuli, a strategy shown above in Figures 1 and 2. Two example on-center cells, $X_{L}$ and $X_{N}$ (Fig. $4 A, B$, top), showed robust responses to a bright spot con-
A

B
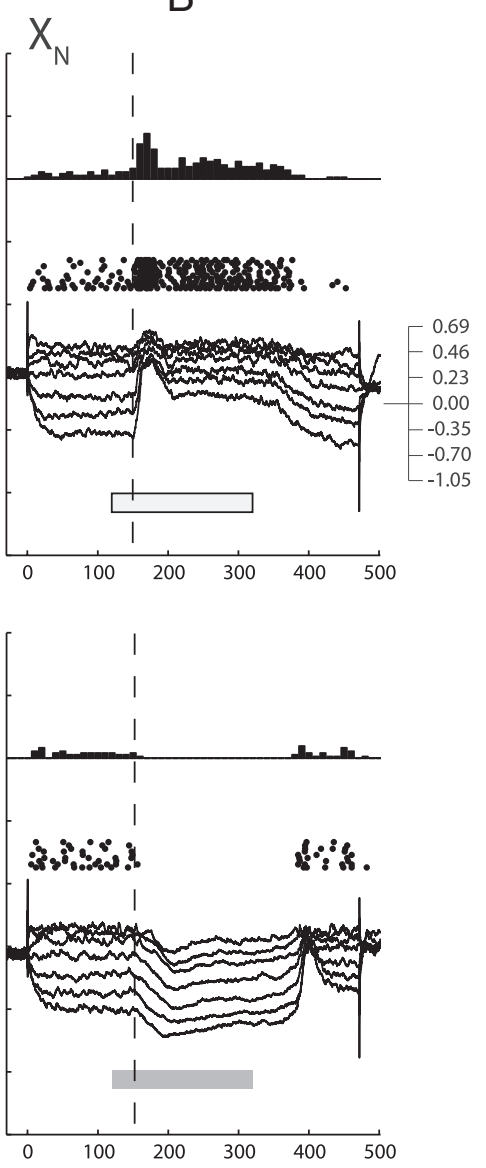

69

0.23

0.00 $-0.70$

\section{(1)}

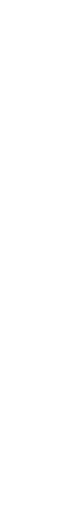

Figure 2. Comparison of responses to same-sign and opposite-sign contrast visual stimuli placed in the RF center. $\boldsymbol{A}$, Lagged cell. Top, Same-sign contrast center stimulus evokes initial inhibition and delayed firing. Bottom, Opposite-sign contrast center Same-sign contrast center stimulus evokes depolarization along with an increase in firing rate. Bottom, Opposite-sign contrast center stimulus evokes a response similar to the lagged cell and stops spiking activity for the duration of the stimulus.

sisting of a strong increase in the frequency of rEPSPs with an onset latency (measured from the hyperpolarized level as in Fig. 3) of $47.6 \mathrm{~ms}$ (Fig. $4 A, \mathrm{X}_{\mathrm{L}}$ ) and $43.8 \mathrm{~ms}$ (Fig. $4 B, \mathrm{X}_{\mathrm{N}}$ ). In both cells, the superimposed single trials show that the abrupt onset of visually driven rEPSPs led to strong temporal summation and sustained depolarization when the cells were held with hyperpolarizing current (current injection onset and offset indicated by upward and downward arrows, respectively). However, injection of depolarizing current revealed that the early portion of the response of the $\mathrm{X}_{\mathrm{L}}$ cell, but not of the $\mathrm{X}_{\mathrm{N}}$ cell, consisted of a small amplitude hyperpolarization ( $3 \mathrm{mV}$ from $-56 \mathrm{mV}$ ).

The effect of the early inhibition in $\mathrm{X}_{\mathrm{L}}$ cells on the latency to firing was clear in the PSTH (Fig. $4 A, B$, bottom) calculated from the responses at the two most depolarized current levels. In this example cell, the half-rise time of the $\mathrm{X}_{\mathrm{L}}$ cell was $100 \mathrm{~ms}$ after a brief and clear suppression of baseline firing and that of the $X_{N}$ cell was $50 \mathrm{~ms}$ (for the population values see Fig. 3). In addition, the PSTH showed the characteristic lower firing rates of the $\mathrm{X}_{\mathrm{L}}$ cells (note difference in $y$-axis scale in PSTH). We removed the spikes from the single trials (see Materials and Methods) and averaged the $V_{\mathrm{m}}$ responses ( $n=11$ trials at each of five current levels; Fig. $4 A, B$, bottom) to estimate the reversal potential $\left(E_{\text {rev }}\right)$ and synaptic conductance ( $G_{\text {syn }}$, see Materials and Methods). Underlying the brief suppression of spike output observed in the PSTH there was a hyperpolarization manifested by injection of 
A
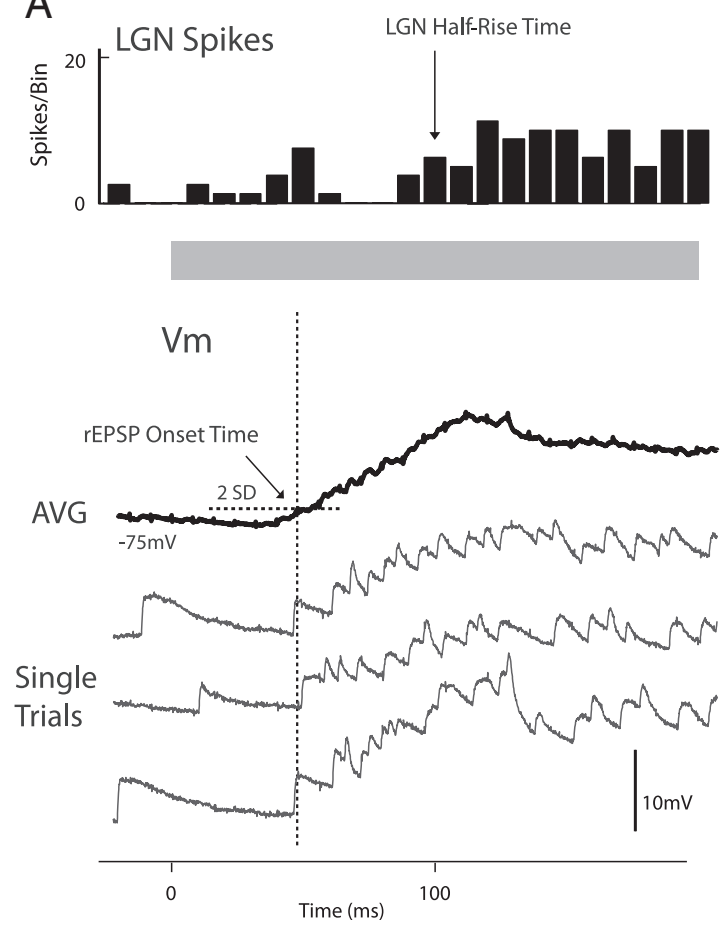

C

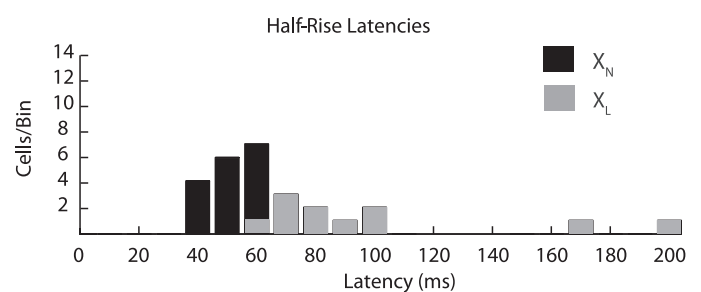

B
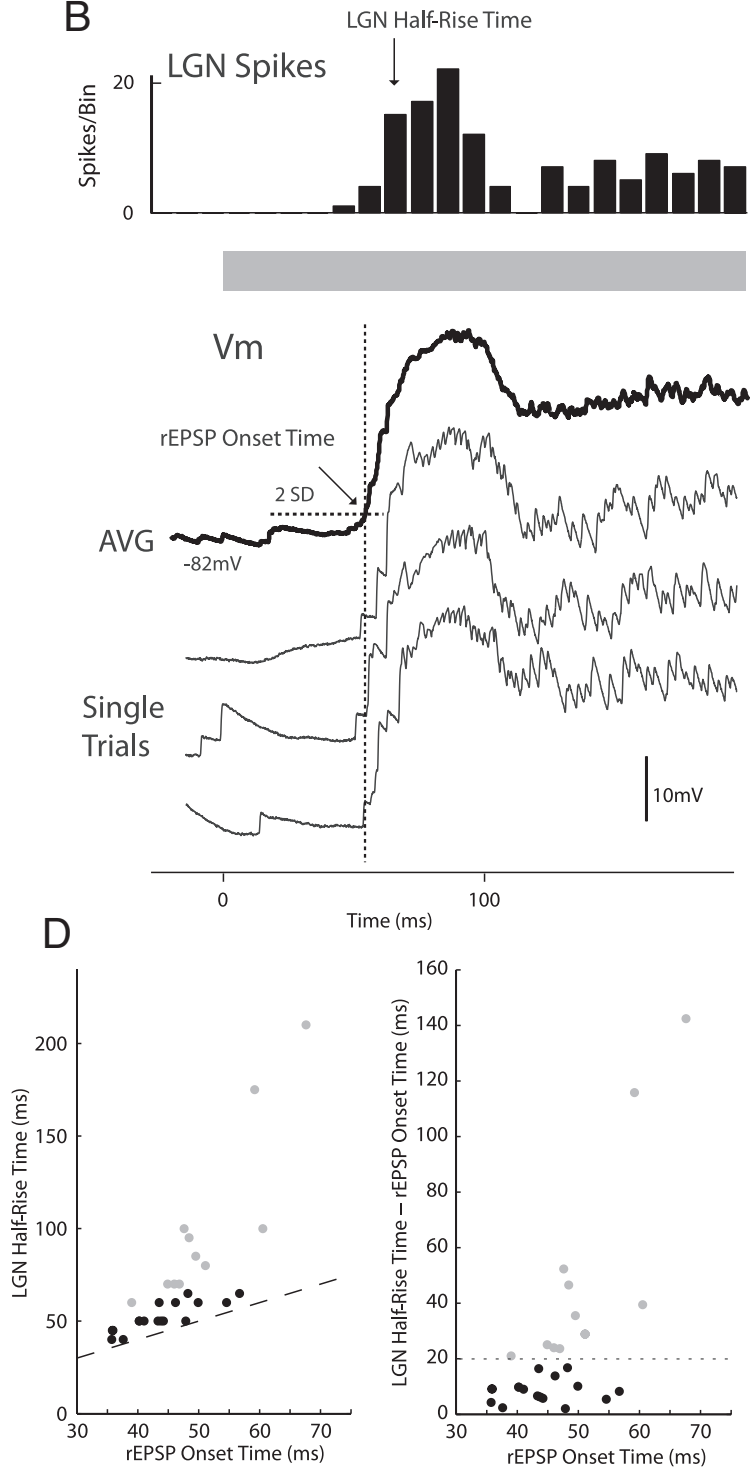

Figure 3. Lagged cell output is delayed relative to retinal input. $A$, PSTH (top), Average $V_{m}$ and individual trials (bottom, held with hyperpolarizing current) of an $X_{L}$ cell in response to a same-sign contrast stimulus placed in the RF center. LGN half-rise time was measured as the bin in which the LGN firing rate reaches a value greater than half the maximal firing rate (down arrow). $r E P S P$ onset measured as the time point (vertical dotted line) when the averaged $V_{\mathrm{m}}$ deviates $2 \mathrm{SD}$ (horizontal dotted line) from steady-state values. $\boldsymbol{B}$, Example measurements for an $\mathrm{X}_{\mathrm{N}}$ cell. $\boldsymbol{C}$, Histogram of latencies to half-maximal firing rate for all cells measured as indicated in $\boldsymbol{A}$. $\boldsymbol{D}, \mathrm{LGN}$ half-rise time plotted against $\mathrm{rEPSP}$ onset time (left) and LGN half-rise time minus rEPSP onset time plotted against rEPSP onset time (right) shows that $X_{L}$ cells (gray) are more delayed relative to their retinal inputs than $X_{N}$ cells (black).

depolarizing current. During this early hyperpolarization the voltage-current relationship was close to linear. The value of $E_{\text {rev }}$ (Fig. $4 C$, red trace) had a time course similar to the hyperpolarization and decreased rapidly to a negative peak at $-63 \mathrm{mV}$ just before the peak of the hyperpolarization. The value of total membrane conductance ( $G_{\text {tot }}$; Fig. $4 C$, blue trace) was $40 \mathrm{nS}$ at rest and rose rapidly during the synaptic response reaching a value of 76 $\mathrm{nS}$ (thus, $G_{\mathrm{syn}}=36 \mathrm{nS}$; see Materials and Methods) at the time of the negative peak of $E_{\text {rev }}$ (indicated by a vertical dotted line), this change represents an increase of $90 \%$ in resting conductance. To compare across the population, we measured $E_{\text {rev }}$ and $G_{\text {syn }}$ values for each cell averaged between 5 and $25 \mathrm{~ms}$ after the onset of the synaptic response.

$\mathrm{X}_{\mathrm{L}}$ cells $(n=11)$ had a mean $E_{\text {rev }}$ of $-64.4 \pm 4.5 \mathrm{mV}$ and a mean $G_{\text {syn }}$ of $40.1 \pm 22.5 \mathrm{nS}$ (Fig. $4 D$ ), whereas $G_{\text {tot }}$ at rest was $46.2 \pm 15.6 \mathrm{nS}$, thus, at the peak of the early inhibition there was an increase in conductance of $88 \%$. In comparison, $\mathrm{X}_{\mathrm{N}}$ cells $(n=$
16) had an $E_{\text {rev }}$ of $-48.2 \pm 9.0 \mathrm{mV}$ (Fig. $3 D$ ), which is lower than what would be expected for a pure excitatory response $(\sim 0 \mathrm{mV})$ and suggests a combination of excitatory and inhibitory conductances as has been shown for sensory responses in LGN (Lindström and Wróbel, 2011), in visual (Borg-Graham et al., 1998), and in other sensory cortices (Wehr and Zador, 2003; Wilent and Contreras, 2005).

The values of $E_{\mathrm{rev}}$ and $G_{\text {syn }}$ in $\mathrm{X}_{\mathrm{L}}$ cells are strongly suggestive of an underlying $\mathrm{GABA}_{\mathrm{A}}$ chloride-mediated IPSP (Crunelli et al., 1988; Paré et al., 1991). These results are consistent with earlier extracellular studies showing that the leading spike suppression in $\mathrm{X}_{\mathrm{L}}$ cells can be eliminated pharmacologically by delivery of $\mathrm{GABA}_{\mathrm{A}}$ receptor blockers at the network level (Heggelund and Hartveit, 1990). We further investigated the ionic basis of the early inhibition at a cellular level by recording from four $\mathrm{X}_{\mathrm{L}}$ cells with $\mathrm{KCl}(3 \mathrm{M})$ in the pipette rather than the control KAc solution. During impalement with $3 \mathrm{M} \mathrm{KCl}$, chloride leaks into the cell 
and changes the $E_{\text {rev }}$ of chloride-mediated responses to more depolarized values (Paré et al., 1991).

In the example $\mathrm{X}_{\mathrm{L}}$ cell in Figure 5, a characteristic leading inhibition with an $E_{\text {rev }}$ of $-63 \mathrm{mV}$ (below spike threshold of $-53 \mathrm{mV}$ and therefore inhibitory) effectively delayed the visually driven increase in firing rate (Fig. 5A). Fifty minutes after impalement the leading inhibitory response changed into a large depolarization leading to high firing rate (Fig. 5B) and the $E_{\text {rev }}$ at the peak of the early inhibition had changed to $-49 \mathrm{mV}$ (Fig. $5 \mathrm{C}$ ), which is above spike threshold and therefore excitatory. The latency from stimulus onset to the half-maximal spike discharge decreased continuously throughout the recording from $70 \mathrm{~ms}$ in the first $5 \mathrm{~min}$, to $50 \mathrm{~ms}$ after $50 \mathrm{~min}$ (Fig. 5D). The absence of early inhibition eliminated the leading spike suppression and the delay to the increased firing rate, effectively transforming this $X_{L}$ cell into an $X_{N}$ cell. Two of three additional $X_{L}$ cells recorded with $3 \mathrm{M}$ $\mathrm{KCl}$ behaved similarly; however, in a fourth cell the early inhibition never evolved into a strong depolarization. These results further substantiate the finding that responses to an excitatory contrast in the center of the RF are delayed in $\mathrm{X}_{\mathrm{L}}$ cells by an early synaptic inhibition mediated by $\mathrm{GABA}_{\mathrm{A}}$ receptors.

Retinal EPSPs are unique in lagged cells Underlying the important response differences between $\mathrm{X}_{\mathrm{L}}$ and $\mathrm{X}_{\mathrm{N}}$ cells is the different synaptic nature of the rEPSPs. The rEPSPs of single input $\mathrm{X}_{\mathrm{L}}$ and $\mathrm{X}_{\mathrm{N}}$ cells are distinct in several ways. First, during spontaneous activity (monitor held at mean luminance), the rEPSPs observed in single input $\mathrm{X}_{\mathrm{L}}$ cells are smaller in amplitude $\left(2.9 \pm 1.3 \mathrm{mV}, n=7, \mathrm{X}_{\mathrm{N}}: 8.2 \pm 3.3\right.$ $\mathrm{mV}, n=10, p<0.001$; Fig. $6 A, B)$ and slower rising (peak slope $=4.6 \pm 2.8 \mathrm{mV}$ / $\mathrm{ms}, \mathrm{X}_{\mathrm{N}}: 19.5 \pm 8.1 \mathrm{mV} / \mathrm{ms}, p<0.001$ ) compared with rEPSPs recorded from single input $\mathrm{X}_{\mathrm{N}}$ cells. Second, whereas the rEPSPs in $X_{N}$ cells appear to decay passively toward rest, $r E P S P s$ in $\mathrm{X}_{\mathrm{L}}$ cells decay more rapidly and terminate in a hyperpolarization (Fig. 6A,C). This late hyperpolarization was reversed by hyperpolarizing the $V_{\mathrm{m}}$ from -61 to $-82 \mathrm{mV}$ with current injection (Fig. $6 \mathrm{C}$, bottom) strongly suggesting an active inhibition with a reversal potential below spike threshold in $\mathrm{X}_{\mathrm{L}}$ cells. Hyperpolarization with current injection in the $\mathrm{X}_{\mathrm{N}}$ cell from -71 to $-87 \mathrm{mV}$ increased the amplitude of the rEPSP but left the decay phase unchanged (Fig. $6 C$, top).

To quantify the difference in decay phase of the rEPSPs between the $\mathrm{X}_{\mathrm{L}}$ and $\mathrm{X}_{\mathrm{N}}$ cells, we averaged rEPSPs at multiple levels of current injection and calculated $E_{\text {rev }}$ of the waveforms $8 \mathrm{~ms}$ after EPSP onset (Fig. 6D). The reversal potential for the population of single input $\mathrm{X}_{\mathrm{L}}$ cells was $-56.0 \pm 9.1 \mathrm{mV}(n=6)$, much
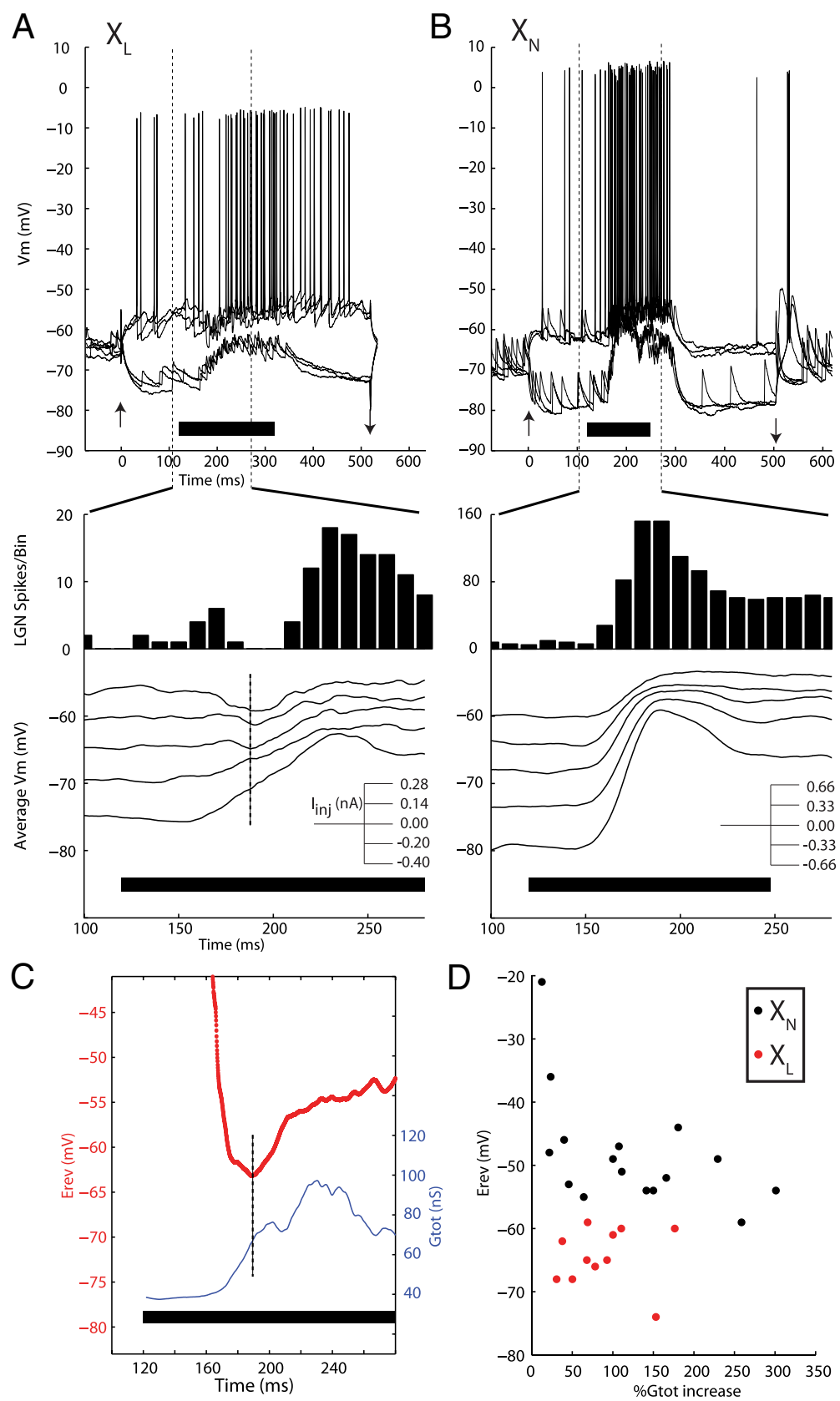

Figure 4. Synaptic responses to a bright stimulus limited to the RF center in typical on-center $X_{L}(\boldsymbol{A})$ and $X_{N}(\boldsymbol{B})$ cells. Top row, Single trials of the complete visual response (represented as black rectangle) are shown for two of the five injected current levels. $\boldsymbol{A}, \boldsymbol{B}$, Bottom, Average $V_{\mathrm{m}}$ for all current levels (after spike removal) at a shorter timescale and spikes as PSTHs. C, Estimates of the reversal potential $\left(E_{\text {rev, }}\right.$, red) and total conductance $\left(G_{\text {tot }}\right.$, blue) are shown for the $X_{L}$ cell as a function of time throughout the response. The reversal potential associated with the leading hyperpolarization in the $X_{L}$ response reaches $-63 m V . D, X_{L}$ and $X_{N}$ cells have large increases in conductance early in the synaptic response; $X_{L}$ cells have more negative reversal potentials.

more negative than the reversal of the single input $\mathrm{X}_{\mathrm{N}}$ population $(-25.3 \pm 28.0 \mathrm{mV}, n=5, p<0.05$; Fig. $6 B$, right $)$. Many single input $\mathrm{X}_{\mathrm{N}}$ cells did not demonstrate a change in amplitude of the decay phase upon hyperpolarization, therefore it was not possible to calculate the associated $E_{\mathrm{rev}}$. These results demonstrate that synaptic input from a single RGC in $\mathrm{X}_{\mathrm{L}}$ cells actually consists of a tightly linked EPSP-IPSP complex as opposed to the simple EPSP in $\mathrm{X}_{\mathrm{N}}$ cells.

We analyzed individual rEPSPs in $\mathrm{X}_{\mathrm{L}}$ cells recorded with $\mathrm{KCl}$ pipettes to determine whether the fast hyperpolarization associated with rEPSPs was mediated by a chloride conductance. One 


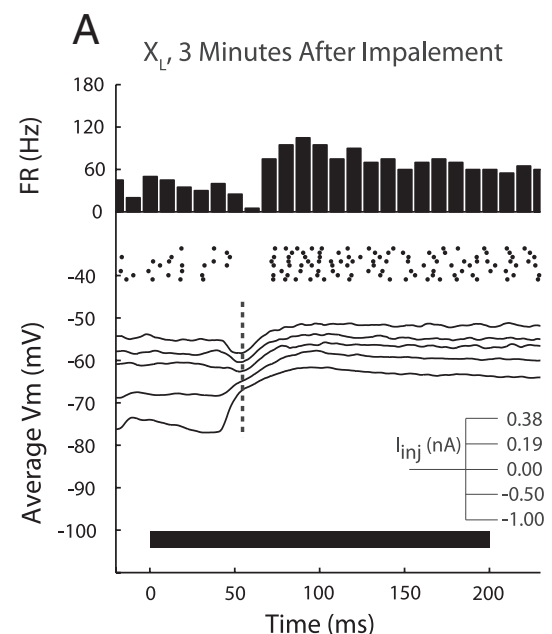

$$
\text { C }
$$

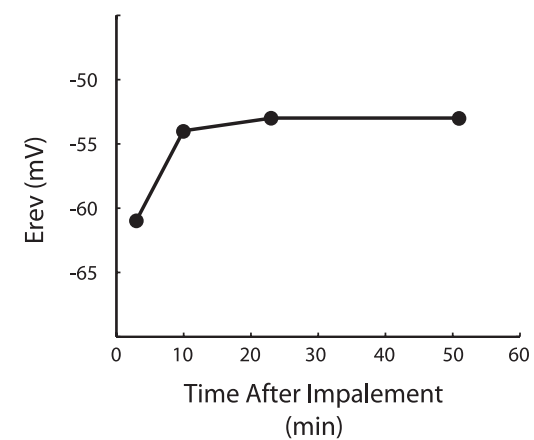

(min)
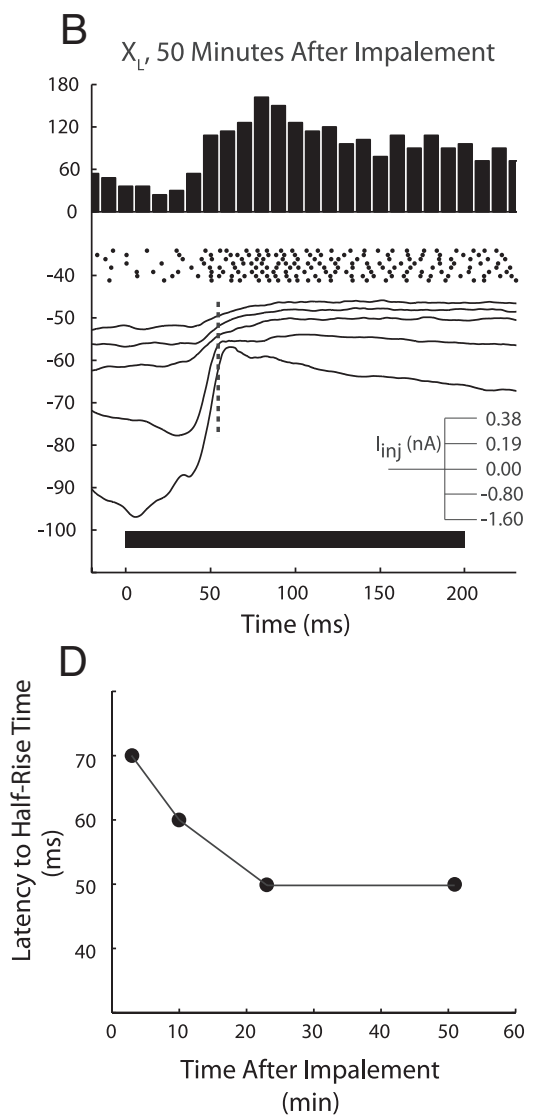

Figure 5. Early synaptic inhibition is mediated by chloride. Recording from an $\mathrm{X}_{\mathrm{L}}$ cell with $3 \mathrm{M} \mathrm{KCl}$ pipette solution. $\boldsymbol{A}$, Three minutes after impalement, the leading inhibition to a same-sign contrast center stimulus was evident as shown by PSTH (top), the spike raster (middle), and the average $V_{m}$ at different current levels (bottom). Time of visual stimulus indicated by black bar below $V_{\mathrm{m}}$ traces. $\boldsymbol{B}$, Fifty minutes after impalement, the hyperpolarization had evolved into a depolarization as the reversal potential for chloride was altered by the presumed diffusion of chloride into the cell. $C, D$, Estimated reversal potential increased and latency to spiking decreased throughout the recording.

hour after impalement of an $\mathrm{X}_{\mathrm{L}}$ cell with a $3 \mathrm{M} \mathrm{KCl}$-filled pipette (Fig. $6 E$ ), the hyperpolarization that followed the rEPSP early in the recording was reversed in polarity, suggesting a chloridemediated process. In contrast, the rEPSP waveforms in $\mathrm{X}_{\mathrm{N}}$ cells were unchanged throughout the duration of the recording with $3 \mathrm{M} \mathrm{KCl}$ (data not shown). We conclude that $\mathrm{X}_{\mathrm{L}}$ cells respond to retinal spikes with an EPSP-Cl ${ }^{-}$-mediated IPSP complex rather than the simple EPSP observed in $\mathrm{X}_{\mathrm{N}}$ cells and suggest that this difference is responsible, at least in part, for the early stimuluslocked inhibition and the resulting distinct temporal behaviors of these two cell classes (Mastronarde, 1987a; Humphrey and Weller, 1988a, b; Heggelund and Hartveit, 1990).

\section{Summation properties of rEPSPs in lagged cells}

We next asked how individual rEPSP-IPSPs seen in $\mathrm{X}_{\mathrm{L}}$ cells produce the macroscopic leading inhibitory response to a step change in contrast. In four single input $\mathrm{X}_{\mathrm{L}}$ cells for which this analysis was possible, the peak firing rate of rEPSPs coincided with the maximum inhibition in the $V_{\mathrm{m}}$ of the early response (Fig. 7A, left, retinal PSTH in gray, $V_{\mathrm{m}}$ in black, averaged across four cells). Furthermore, as the firing rate of the retinal input dropped to its sustained level, the $\mathrm{X}_{\mathrm{L}}$ cell escaped from the inhibition and the membrane potential slowly depolarized leading to delayed output of the $\mathrm{X}_{\mathrm{L}}$ cell (Fig. 7A, left). This was in contrast with the response of $X_{N}$ cells, in which the increase in rate of
rEPSPs during the visual response is accompanied by depolarization (Fig. $7 A$, right) and accelerating firing rate.

One possible explanation for this escape from inhibition is that $\mathrm{X}_{\mathrm{L}}$ cells have unique rates of adaptation for excitation and inhibition (Blitz and Regehr, 2005; Augustinaite and Heggelund, 2007). We explored this possibility by comparing the waveforms of averaged rEPSPs that occurred early in the response, defined as the time between the onset of the response and the peak of the hyperpolarization (Fig. 7A, Early) with the averaged rEPSPs occurring late in the response, defined as the $40 \mathrm{~ms}$ period following the peak of the hyperpolarization (Fig. 7A, Late). The resulting averaged early (continuous lines) and late (dotted lines) rEPSPs are shown in Figure $7 B$. To compare the EPSPs we measured their peak depolarization from baseline (Fig. 7C, "b-a") and the amplitude of the hyperpolarization from the peak (Fig. 7C, "c-b"). For all four $\mathrm{X}_{\mathrm{L}}$ cells, rEPSPs occurring early in the response exhibited stronger inhibition (c-b) than those occurring late $(-2.8 \pm 0.8 \mathrm{mV}$ vs $-0.4 \pm 0.3 \mathrm{mV}, p<0.001$; Fig. $7 C$, right; also significant measured as $\mathrm{c}-\mathrm{a}, p<0.05$ ), but showed similar peak amplitudes $(2.8 \pm 1.6 \mathrm{mV}$ vs $1.9 \pm 0.6 \mathrm{mV}, p>0.1$; Fig. $7 C, \mathrm{~b}-\mathrm{a})$. As a consequence of the different dynamic behaviors of the excitatory and inhibitory phases of the rEPSP in $\mathrm{X}_{\mathrm{L}}$ cells, the stronger inhibition early in the response causes the rapid train of rEPSPs to hyperpolarize the cell while rEPSPs later in the response are able to summate and depolarize the cell (Fig. 7D). This hypothesis is supported by examination of single trials as in Figure $7 D$, in which early rEPSPs lead to sizable hyperpolarization while late rEPSPs sum temporally to generate depolarization.

In summary, $\mathrm{a} \mathrm{Cl}^{-}$-dependent repolarization of rEPSPs in $\mathrm{X}_{\mathrm{L}}$ cells, but not in $\mathrm{X}_{\mathrm{N}}$ cells, is responsible for the early inhibitory response to same-sign contrast stimuli of $\mathrm{X}_{\mathrm{L}}$ cells. Furthermore, the smaller EPSPs in $\mathrm{X}_{\mathrm{L}}$ cells lead to slower summation rates and lower firing rates in $\mathrm{X}_{\mathrm{L}}$ cells compared with $\mathrm{X}_{\mathrm{N}}$ cells.

\section{Discussion}

Our results demonstrate for the first time in vivo the presence of fast, chloride-dependent inhibition following single rEPSPs at short latency ( $\sim 1 \mathrm{~ms})$ during visual responses in the cat LGN. This form of visually driven feedforward inhibition is only present in a subclass of $\mathrm{X}$-cells, the lagged cells $\left(\mathrm{X}_{\mathrm{L}}\right)$, and is responsible for their two defining visual response properties: (1) the delay of spike output in response to a same-sign contrast center stimulus and (2) the lower and more sustained firing rate in their visual responses compared with nonlagged $\mathrm{X}$-cells $\left(\mathrm{X}_{\mathrm{N}}\right)$. The rapid temporal summation of the IPSPs at response onset generates a powerful early inhibition that suppresses spike output and delays the visual response. However, the IPSP rapidly adapts thus allowing rEPSPs to summate and depolarize the cell leading to the delayed spike output. The lower firing rates in $\mathrm{X}_{\mathrm{L}}$ cells are due to the 
smaller and faster decaying rEPSPs as they are shaped by the presence of $\mathrm{Cl}^{-}$dependent inhibition. Indeed, our intracellular recordings with $\mathrm{KCl}$-filled pipettes reversed the IPSP associated with the rEPSP and modified the response properties of $\mathrm{X}_{\mathrm{L}}$ cells leading to (1) the loss of the early spike suppression, (2) the elimination of the delay to an increase in firing rate by which $\mathrm{X}_{\mathrm{L}}$ cells are defined, and (3) increase in firing rate during visual response. $\mathrm{KCl}$ recordings from $\mathrm{X}_{\mathrm{N}}$ cells were indistinguishable from control recordings with KAc. Similar effects on response properties of $\mathrm{X}_{\mathrm{L}}$ cells were observed in extracellular recordings after local application of $\mathrm{GABA}_{\mathrm{A}}$ antagonists (Heggelund and Hartveit, 1990).

We attribute this fast form of inhibition to the action of the triadic synapses that characterize $\mathrm{X}_{\mathrm{L}}$ cells (Humphrey and Weller, 1988b) and provide the first intracellular evidence in vivo supporting a functional role of this unique synaptic structure in thalamus.

\section{Lagged cells}

Lagged cells were discovered by Mastronarde (1987a) in the cat thalamus using simultaneous extracellular recordings of RGCs and their postsynaptic LGN neurons. Mastronarde (1987a) distinguished $\mathrm{X}_{\mathrm{N}}$ and $\mathrm{X}_{\mathrm{L}}$ cell classes based in part on a parametric analysis that included a bimodal distribution of visual latencies. However, he excluded cells that he called "partially lagged." A subsequent study showed that the visual latency distribution is essentially continuous (Wolfe and Palmer, 1998) but refers to cells at the extremes of the time course distribution as lagged and nonlagged due to their drastically different response properties. Our intracellular data also show a continuous and wide distribution of visual latencies. However, relative to their retinal inputs, all $\mathrm{X}_{\mathrm{L}}$ cells had latencies $>20 \mathrm{~ms}$ whereas all $\mathrm{X}_{\mathrm{N}}$ cells had latencies $<20 \mathrm{~ms}$ (Fig. 3 C).

This delay in firing in $\mathrm{X}_{\mathrm{L}}$ cells is due to the strong initial synaptic inhibition, which defines our population of lagged cells.

In Mastronarde's (1987a) study, cross-correlation of retinal and geniculate lagged cells exhibited a large dip following the monosynaptic peak. Furthermore, they were poorly driven by their retinal excitatory afferents despite the fact that these lagged cells were single input cells as were their nonlagged counterparts. Our results show that these two response properties are likely due to feedforward inhibition recruited by each rEPSP, and the smaller rEPSP amplitudes in $\mathrm{X}_{\mathrm{L}}$ cells.

The functional role served by lagged cells is likely the generation of direction selectivity in cortex. It has been proposed that the convergence of LGN cells whose RFs are offset in space and time $\left(\mathrm{X}_{\mathrm{N}}\right.$ and $\mathrm{X}_{\mathrm{L}}$ cells) produces RFs of thalamorecipient L4 cortical cells that are oriented in space-time (Saul and
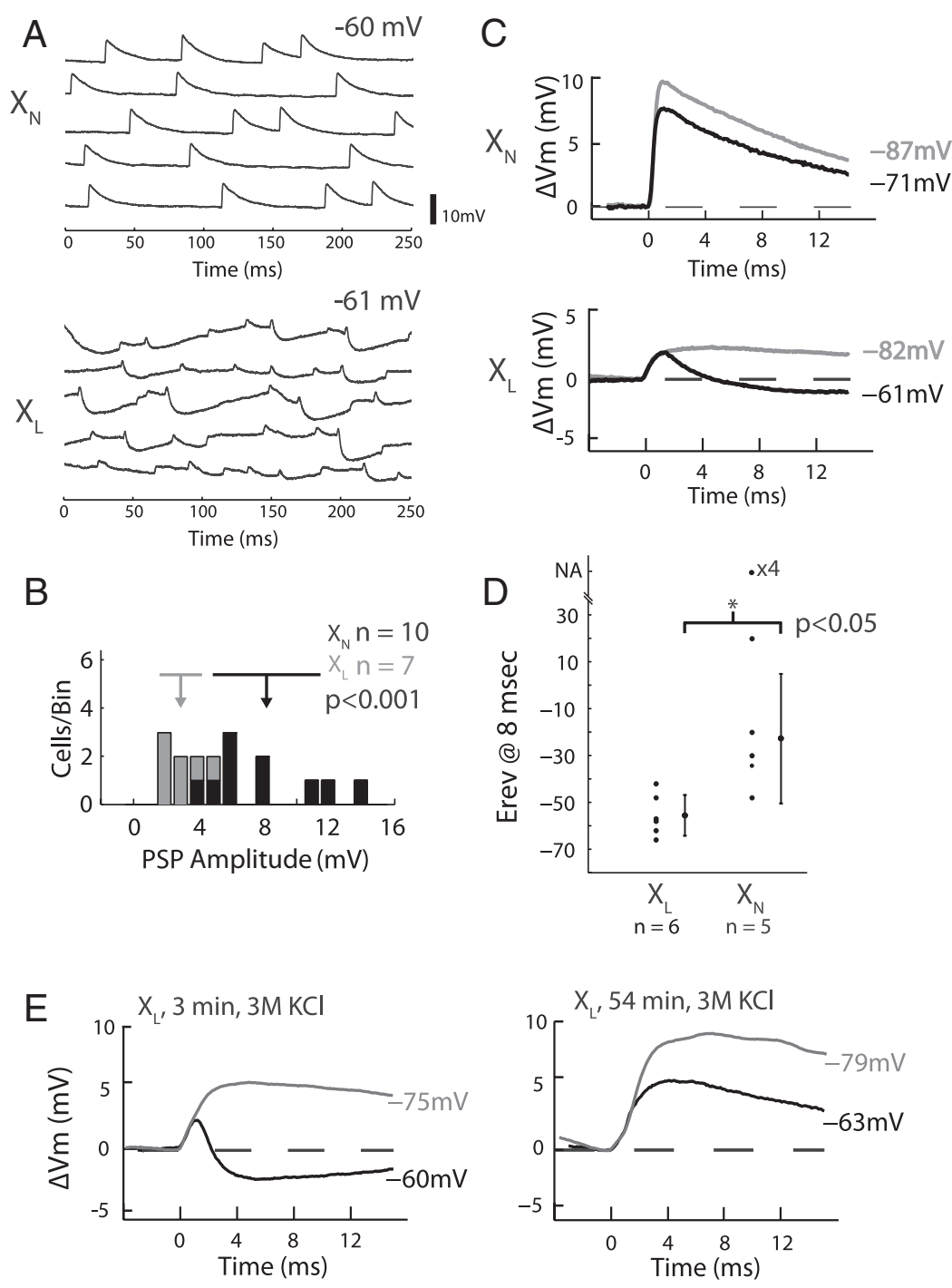

Figure 6. Differences in $X_{L}$ and $X_{N}$ cell rEPSPs. $A$, Five sample $V_{m}$ traces showing spontaneous rEPSPs for $X_{N}$ (top) and $X_{L}$ (bottom) LGN cells. Traces displaced vertically. $\boldsymbol{B}$, Distribution of rEPSP amplitudes for both cell types. Means indicated by downward arrows SDs indicated by horizontal lines. $C$, Superimposed average of rEPSPs made at resting $V_{m}$ (black trace) and during hyperpolarizing $\boldsymbol{E}$, Averaged spontaneous rEPSPs in an $\mathrm{X}_{\mathrm{L}}$ cell just after impalement (left) and $1 \mathrm{~h}$ after impalement (right) with $3 \mathrm{M} \mathrm{KCl}$ in the pipette. Black and gray traces as in $\boldsymbol{C}$.

Humphrey, 1990) and direction selective. As predicted by Adelson and Bergen (1985) and demonstrated by McLean and Palmer (1989), direction-selective L4 simple cells do indeed exhibit spacetime oriented RFs and the preferred direction and velocity can be largely accounted for by a linear mechanism (Reid et al., 1987).

\section{Inhibition in thalamus and triadic synapses}

Inhibitory input to LGN relay cells originates from two types of GABAergic neurons, the neurons of the perigeniculate nucleus (PGN) and local circuit interneurons interspersed within the LGN. Inputs from PGN are located on more distal dendrites than those from interneurons and their role in visual processing is still unknown.

Thalamic interneurons form GABAergic release sites from axonal terminals (F1 terminals) and from enlarged presynaptic spe- 
A
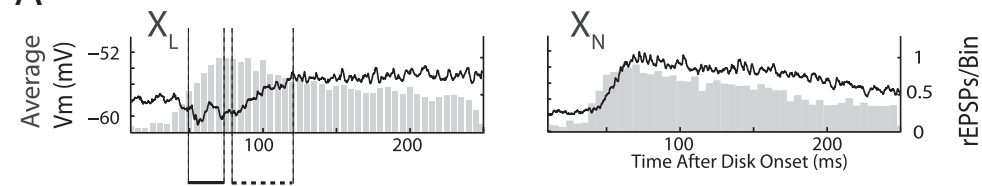

B
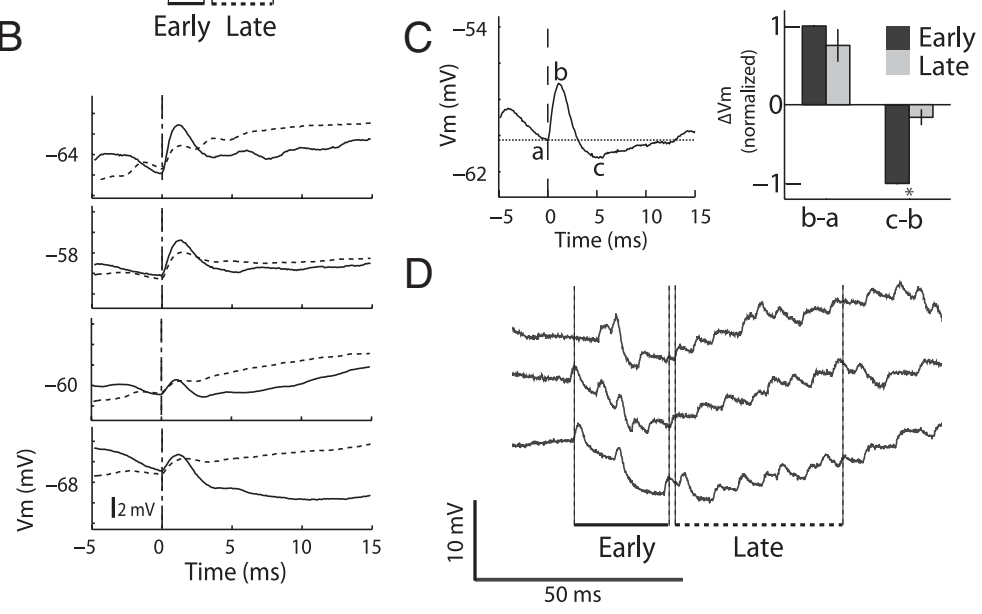

Figure 7. EPSP-IPSP waveform evolves during the response to flashed visual stimuli. $\boldsymbol{A}$, Average LGN $V_{\mathrm{m}}$ (black trace) and normalized PSTH (light gray) of RGC firing following a flashed same-sign contrast stimulus. Plots are averages of four $X_{L}$ (left) and four $X_{N}$ (right) cells. Maximal RGC firing rate occurs during hyperpolarization of the $X_{L}$ cell $V_{m}$. $\ln X_{N}$ cells, peak RGC firing rate closely matches peak depolarization. $\boldsymbol{B}$, Averaged rEPSPs taken from early (solid line) and late (dashed line) in the macroscopic responses of four $X_{L}$ cells. $C$, IPSP amplitude is measured as the difference of the peak and trough of the waveform, and is reduced late in the response when the $V_{m}$ begins to depolarize, as shown in the bar graph at right. Change in IPSP amplitude is significant while the change in the EPSP amplitude is not. $\boldsymbol{D}$, Single trials that show that the rapid train of rEPSPs initially hyperpolarize the cell and later depolarize the cell.

cializations formed at the end of long, thin dendritic processes (F2 terminals). Many F2 terminals are part of triadic arrangements in which they are postsynaptic to RGC axons and presynaptic to thalamic relay neuron dendrites. These triadic synaptic structures are a feature characteristic of most thalamic nuclei (Famiglietti and Peters, 1972; Hamos et al., 1985). The triadic postsynaptic sites to $\mathrm{F} 2$ terminals are particularly large in $\mathrm{X}_{\mathrm{L}}$ cells and form clusters that have been described as grape-like appendages, perhaps betraying their functional importance (Humphrey and Weller, 1988b). Triadic synapses are ensheathed by glial processes into structures called glomeruli.

The simplest interpretation of our results is that the rEPSPIPSP complex seen in $\mathrm{X}_{\mathrm{L}}$ cells is mediated by the triadic synaptic structures within the glomeruli. Although other schemes are compatible with our data, the use of the feedforward inhibitory synapse would inherently allow for the omnipresence of the inhibitory component of the rEPSP-IPSP complex seen only in $\mathrm{X}_{\mathrm{L}}$ cells. This idea is supported by the anatomical studies of Humphrey and Weller (1988b) who showed the $\mathrm{X}_{\mathrm{L}}$ cell pathway to be dominated by the glomerular circuits.

The presence of small and short latency $\mathrm{GABA}_{\mathrm{A}}$-mediated IPSPs in thalamic relay cells probably of glomerular origin was first shown in anterior thalamic nuclei in cat in vivo (Paré et al., 1991), which are devoid of reticular input. In the LGN, the presence of GABAergic inhibition time locked ( $\sim 1$ ms delay) to single electrically evoked rEPSPs was demonstrated in cat in vivo (Bloomfield and Sherman, 1988) and in mouse LGN slices in vitro (Blitz and Regehr, 2005). In response to brief electrical stimulation of the optic tract, $34 \%$ of mouse LGN relay neurons showed inhibition reliably following, and with the same activation threshold, as single inputs from the retina, while the remaining LGN neurons showed inhibition with varying latencies and a variable threshold. The time-locked inhibition was a $\mathrm{GABA}_{\mathrm{A}}, \mathrm{Cl}^{-}$-mediated current most likely mediated by the triadic synapse and it is virtually identical to the inhibition we show here in $\mathrm{X}_{\mathrm{L}}$ cells in vivo. Finally, a recent study in cat LGN by Lindström and Wróbel (2011) demonstrated that X-cells respond to same-sign contrast center stimuli with strong feedforward IPSPs and suggested that this is likely a result of triadic circuitry, although they did not find differences between lagged and nonlagged cells.

\section{Adaptation of inhibition}

In contrast to the small variability in rEPSP amplitude, the amplitude of the associated IPSP is highly variable suggesting complex underlying dynamics. Changes in IPSP amplitude are particularly important at the onset of the visual response. The fast and strong IPSP summation, which generates the characteristic early inhibition of $\mathrm{X}_{\mathrm{L}}$ cells, and which coincides with the highest firing frequency of the retinal input, is followed by rapid adaptation that allows $\mathrm{X}_{\mathrm{L}}$ cells to escape inhibition and generate a sustained and delayed discharge. While different mechanisms could underlie this adaptation, one possibility is that synaptic depression of the triadic-mediated IPSP builds during the phasic portion of the RGC discharge. In fact, Blitz and Regehr (2005) showed such adaptation in mouse LGN in vitro; however, it was extremely fast since only the first rEPSP was followed by an IPSP. In our data, the IPSP does not diminish entirely after the first rEPSP, but over the first $\sim 20 \mathrm{~ms}$ of the response, possibly a difference in the dynamics of adaptation in cat LGN. Another possibility for the lability of inhibition is a change in the $E_{\text {rev }}$ of chloride ions due to postsynaptic chloride accumulation. In hippocampal pyramidal cells, repetitive activation of $\mathrm{GABA}_{\mathrm{A}}$ IPSCs led to changes in the reversal potential of chloride without any changes in conductance and were thus not attributable to $\mathrm{GABA}_{\mathrm{A}}$ desensitization (Huguenard and Alger, 1986). This shift occurred in seconds rather than a few milliseconds as in our data; however, recordings in the hippocampus were done in the soma of large dissociated pyramidal cells. In contrast, the postsynaptic elements of $\mathrm{X}_{\mathrm{L}}$ cells are only a few micrometers across.

An alternate explanation for the larger amplitude and phasic nature of the early inhibition in response to a visual stimulus is the engagement of axodendritic feedforward inhibition elicited by interneuronal spiking (Paré et al., 1991; Blitz and Regehr, 2005; Acuna-Goycolea et al., 2008). Interneuronal spiking would generate an F1-mediated IPSP and back propagate into the dendrites activating all F2 synapses (Acuna-Goycolea et al., 2008; Casale and McCormick, 2011). This scenario may account for the discrepancy between the $E_{\text {rev }}$ of the IPSPs associated with the visually evoked macroscopic response $(-64 \mathrm{mV})$ and the $E_{\mathrm{rev}}$ of rEPSPs occurring outside of visual responses $(-56 \mathrm{mV})$, in which perhaps only a subset of F2 terminals and no F1 terminals are activated. Indeed, LGN interneurons possess intrinsic properties that boost excitability and dramatically change propagation of excitation within the somatodendritic tree by engaging sodium 
and calcium dendritic conductances and making it likely that complex patterns of interneuronal activation are engaged by visual input (Acuna-Goycolea et al., 2008).

An additional contributor to the build-up of excitation after the early inhibition and the sustained and prolonged discharge of $\mathrm{X}_{\mathrm{L}}$ cells during the visual response may be the activation of NMDA receptors, which have been shown to mediate a moderate to a large portion of $\mathrm{X}_{\mathrm{L}}$ cell excitatory responses (Heggelund and Hartveit, 1990; Kwon et al., 1991; Augustinaite and Heggelund, 2007).

\section{Other roles of triadic synapses}

In addition to causing a delay in lagged cells on the order of tens of milliseconds, it has been proposed that the main role of triadic synapses is to modulate the gain of retinogeniculate transmission on the timescale of seconds (Sherman, 2004). For example, activation of metabotropic glutamate receptors in F2 terminals postsynaptic to retinal inputs generate long lasting (>100 ms) depolarization of the GABAergic terminals increasing visually driven inhibition and consequently decreasing the gain of the retinogeniculate synapse (Cox and Sherman, 2000). In addition, the amplitude of triadic inhibition is modulated by acetylcholine, as activation of muscarinic $\mathrm{M} 2$ type receptors in the F2 terminal reduces GABA release (Cox and Sherman, 2000). Indeed, electrical stimulation of the parabrachial nucleus, which supplies cholinergic input to the glomeruli, leads to a $300-500 \%$ increase of the responses to optic chiasm stimulation (Wolfe and Palmer, 1998).

Here we have shown that lagged cells have unique synaptic events, which cause their delayed visual response. Triadic synapses are likely responsible for the distinct temporal dynamics in lagged cells by supplying a feedforward inhibition tightly locked to retinal excitation.

\section{References}

Acuna-Goycolea C, Brenowitz SD, Regehr WG (2008) Active dendritic conductances dynamically regulate GABA release from thalamic interneurons. Neuron 57:420-431. CrossRef Medline

Adelson EH, Bergen JR (1985) Spatiotemporal energy models for the perception of motion. J Opt Soc Am A 2:284-299. CrossRef Medline

Augustinaite S, Heggelund P (2007) Changes in firing pattern of lateral geniculate neurons caused by membrane potential dependent modulation of retinal input through NMDA receptors. J Physiol 582:297-315. CrossRef Medline

Blitz DM, Regehr WG (2005) Timing and specificity of feed-forward inhibition within the LGN. Neuron 45:917-928. CrossRef Medline

Bloomfield SA, Sherman SM (1988) Postsynaptic potentials recorded in neurons of the cat's lateral geniculate nucleus following electrical stimulation of the optic chiasm. J Neurophysiol 60:1924-1945. Medline

Borg-Graham LJ, Monier C, Frégnac Y (1998) Visual input evokes transient and strong shunting inhibition in visual cortical neurons. Nature 393: 369-373. CrossRef Medline

Casale AE, McCormick DA (2011) Active action potential propagation but not initiation in thalamic interneuron dendrites. J Neurosci 31: 18289-18302. CrossRef Medline

Cox CL, Sherman SM (2000) Control of dendritic outputs of inhibitory interneurons in the lateral geniculate nucleus. Neuron 27:597-610. CrossRef Medline

Crunelli V, Haby M, Jassik-Gerschenfeld D, Leresche N, Pirchio M (1988) $\mathrm{Cl}^{-}$- and $\mathrm{K}+$-dependent inhibitory postsynaptic potentials evoked by interneurones of the rat lateral geniculate nucleus. J Physiol 399:153-176. Medline

Enroth-Cugell C, Robson JG (1966) The contrast sensitivity of retinal ganglion cells of the cat. J Physiol 187:517-552. Medline

Famiglietti EV Jr, Peters A (1972) The synaptic glomerulus and the intrinsic neuron in the dorsal lateral geniculate nucleus of the cat. J Comp Neurol 144:285-334. CrossRef Medline

Fernald R, Chase R (1971) An improved method for plotting retinal landmarks and focusing the eyes. Vision Res 11:95-96. CrossRef Medline

Hamos JE, Van Horn SC, Raczkowski D, Uhlrich DJ, Sherman SM (1985) Synaptic connectivity of a local circuit neurone in lateral geniculate nucleus of the cat. Nature 317:618-621. CrossRef Medline

Heggelund P, Hartveit E (1990) Neurotransmitter receptors mediating excitatory input to cells in the cat lateral geniculate nucleus. I. Lagged cells. J Neurophysiol 63:1347-1360. Medline

Higley MJ, Contreras D (2003) Nonlinear integration of sensory responses in the rat barrel cortex: an intracellular study in vivo. J Neurosci 23: 10190-10200. Medline

Hoffmann KP, Stone J, Sherman SM (1972) Relay of receptive-field properties in dorsal lateral geniculate nucleus of the cat. J Neurophysiol 35: 518-531. Medline

Hubel DH, Wiesel TN (1961) Integrative action in the cat's lateral geniculate body. J Physiol 155:385-398. Medline

Huguenard JR, Alger BE (1986) Whole-cell voltage-clamp study of the fading of GABA-activated currents in acutely dissociated hippocampal neurons. J Neurophysiol 56:1-18. Medline

Humphrey AL, Weller RE (1988a) Functionally distinct groups of X-cells in the lateral geniculate nucleus of the cat. J Comp Neurol 268:429-447. CrossRef Medline

Humphrey AL, Weller RE (1988b) Structural correlates of functionally distinct X-cells in the lateral geniculate nucleus of the cat. J Comp Neurol 268:448-468. CrossRef Medline

Jahnsen H, Llinás R (1984) Electrophysiological properties of guinea-pig thalamic neurones: an in vitro study. J Physiol 349:205-226. Medline

Jin J, Wang Y, Lashgari R, Swadlow HA, Alonso JM (2011) Faster thalamocortical processing for dark than light visual targets. J Neurosci 31:1747117479. CrossRef Medline

Kwon YH, Esguerra M, Sur M (1991) NMDA and non-NMDA receptors mediate visual responses of neurons in the cat's lateral geniculate nucleus. J Neurophysiol 66:414-428. Medline

Lindström S, Wróbel A (2011) Feedforward and recurrent inhibitory receptive fields of principal cells in the cat's dorsal lateral geniculate nucleus. Pflugers Arch 461:277-294. CrossRef Medline

Mastronarde DN (1987a) Two classes of single-input X-cells in cat lateral geniculate nucleus. I. Receptive-field properties and classification of cells. J Neurophysiol 57:357-380. Medline

Mastronarde DN (1987b) Two classes of single-input X-cells in cat lateral geniculate nucleus. II. Retinal inputs and the generation of receptive-field properties. J Neurophysiol 57:381-413. Medline

McLean J, Palmer LA (1989) Contribution of linear spatiotemporal receptive field structure to velocity selectivity of simple cells in area 17 of cat. Vision Res 29:675-679. CrossRef Medline

Niell CM, Stryker MP (2008) Highly selective receptive fields in mouse visual cortex. J Neurosci 28:7520-7536. CrossRef Medline

Paré D, Dossi RC, Steriade M (1991) Three types of inhibitory postsynaptic potentials generated by interneurons in the anterior thalamic complex of cat. J Neurophysiol 66:1190-1204. Medline

Reid RC, Soodak RE, Shapley RM (1987) Linear mechanisms of directional selectivity in simple cells of cat striate cortex. Proc Natl Acad Sci U S A 84:8740-8744. CrossRef Medline

Saul AB (2008) Lagged cells. Neurosignals 16:209-225. CrossRef Medline

Saul AB, Humphrey AL (1990) Spatial and temporal response properties of lagged and nonlagged cells in cat lateral geniculate nucleus. J Neurophysiol 64:206-224. Medline

Sherman SM (2004) Interneurons and triadic circuitry of the thalamus. Trends Neurosci 27:670-675. CrossRef Medline

Wehr M, Zador AM (2003) Balanced inhibition underlies tuning and sharpens spike timing in auditory cortex. Nature 426:442-446. CrossRef Medline

Wilent WB, Contreras D (2005) Dynamics of excitation and inhibition underlying stimulus selectivity in rat somatosensory cortex. Nat Neurosci 8:1364-1370. CrossRef Medline

Wolfe J, Palmer LA (1998) Temporal diversity in the lateral geniculate nucleus of cat. Vis Neurosci 15:653-675. Medline 